\title{
0 ENTRELAÇAMENTO DE ESTETICISMO E UTOPIA NA OBRA DE RICHARD RORTY
}

\author{
Ricardo Corrêa de Araújo \\ Universidade Federal do Espírito Santo
}

\begin{abstract}
This article try to investigate the interlacement of two themes associated to Richard Rorty's work: estheticism and utopia. Our pretension is to show how he thinks the interaction between both of them by way of to dissolve the critical of thinkers like Habermas, showing the estheticism like a kind of strategy to favor his liberal utopia.
\end{abstract}

Key-words: Contemporaneous philosophy, Richard Rorty, estheticism, utopia.

Resumo: Este artigo tenta investigar o entrelaçamento de dois temas associados à obra de Richard Rorty: esteticismo e utopia. Nossa pretensão é mostrar como ele pensa a interação entre ambos de modo a dissolver as críticas de pensadores como Habermas, mostrando 0 esteticismo não como uma falha, mas como uma espécie de estratégia para favorecer sua utopia liberal.

Palavras-chave: Filosofia contemporânea, Richard Rorty, esteticismo, utopia.

As expressões "esteticismo" e "utopia” não gozam de grande prestígio no mundo contemporâneo. Ambas são utilizadas para designar certa debilidade da razão. Uma incompetência para, respectivamente, permanecer no âmbito argumentativo e avaliar pragmaticamente a realidade. Estas duas formas de inconseqüência não costumam aparecer nas idéias de um mesmo pensador, bastando a ocorrência de uma delas para que se estabeleça certa desconfiança ou, até mesmo, censura aberta. As acusações de esteticismo, no interior da filosofia, são habituais contra parte significativa da tradição francesa contemporânea ligada à herança nietzschiana. Nomes como Derrida, Foucault, Deleuze e Lyotard têm suas obras vistas como esteticistas, 
justamente na medida em que privilegiam o uso de um vocabulário repleto de inovações lingüísticas e de referências ao campo estético: “(...) os filósofos franceses se especializaram em tentar estabelecer o que Lyotard chama maîtrise de la parole et $d u$ sens engajando-se em 'crítica radical' - isto é, inventando um novo vocabulário que torna todos os antigos temas de debates políticos e filosóficos obsoletos"1. Este vocabulário esteticista, conhecido por sua crítica à metafísica, também buscou tornar obsoletos discursos utópicos da tradição ocidental, as chamadas metanarrativas legitimadoras, tais como a do Esclarecimento, do Idealismo ou do Marxismo. Por outro lado, ao menos a primeira destas utopias foi adotada no pensamento contemporâneo, através de uma espécie de renovação do projeto da modernidade proposta por Jürgen Habermas, para quem não deveríamos falar em pós-modernidade, como Lyotard, mas sim do projeto inacabado da modernidade, isto é, da possibilidade de continuação dos ideais de emancipação ainda contidos virtualmente e à espera de realização nas sociedades democráticas contemporâneas. Contra este tipo de discurso neoiluminista utópico, não há críticas de esteticismo, mas de seu inverso, isto é, de um fundacionismo universalista insustentável, de uma hybris argumentativa anacrônica.

Os exemplos apresentados são uma significativa amostra das principais posições acusadas de esteticismo e vinculadas ao utopismo, bem como da oposição entre tais posicionamentos. Todavia, a obra madura do pensador americano Richard Rorty reúne esteticismo e utopismo sob a inspiração de um neopragmatismo matizado pela hermenêutica de inspiração heideggeriana. Isto significa que ele ocupa uma posição complexa e original no cenário filosófico. Como se não bastasse, Rorty percorreu uma trajetória incomum, circulando entre as principais tradições do pensamento contemporâneo, muitas vezes antagônicas. $\mathrm{O}$ que segue é uma tentativa de compreensão desta posição como uma reunião "metodológica" de esteticismo e utopia, isto é, como proposta utópica a ser construída a partir de uma estratégia que se pode considerar esteticista, na medida em que não concede o privilégio à argumentação, mas à criação de um novo vocabulário. Esta

1 "(...) os filósofos franceses se especializaram em tentar estabelecer o que Lyotard chama maîtrise de la parole e du sens engajando-se em 'crítica radical' - isto é, inventando um novo vocabulário que torna todos os antigos temas de debates políticos e filosóficos obsoletos" (RORTY, R. Objetivismo, relativismo e verdade. Rio de Janeiro: Relume-Dumará, 2002, p. 292.). 
tentativa de compreensão da utopia liberal de Rorty será realizada, em boa medida, através do constante diálogo que ele buscou com o esteticismo e o utopismo, justamente nas figuras de Lyotard e de Habermas, mas também das críticas que lhe foram dirigidas pelo pensador que talvez lhe estivesse mais próximo nos últimos anos de vida, o filósofo italiano Gianni Vattimo.

Em uma dupla reveladora e polêmica de ensaios ${ }^{2}$, Rorty apresentou sua intrigante trajetória acadêmico-intelectual, desde sua admissão como professor de filosofia em Princeton até sua recente proposta utópica, construída a partir da ascensão de uma cultura literária ${ }^{3}$. Entre uma e outra, decorreram os quase cinqüenta anos que consolidaram a bem conhecida divisão da filosofia entre aquela geralmente praticada no mundo anglo-saxão e a que predomina no restante do mundo, especialmente no velho continente: "O antagonismo entre a filosofia analítica e a não-analítica [ou continen-

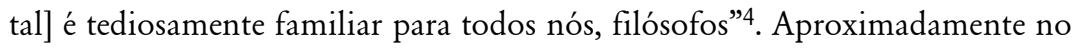
meio desse caminho, no fim da década de setenta, Rorty produziu seu livro mais conhecido, habitualmente considerado sua principal obra de longo fôlego, "A filosofia e o espelho da natureza", marco de uma reviravolta em seu percurso teórico, que se afastou consideravelmente do inicial ambiente analítico em direção a uma atualização do pragmatismo de John Dewey e a um amigável diálogo com autores como Heidegger e Derrida, muito distantes daquele meio, a ponto de serem habitualmente estudados fora dos departamentos de filosofia nas universidades americanas:

(...) os departamentos de filosofia americanos estão freqüentemente contentes em ter figuras como Hegel, Heidegger, Derrida e Foucault ensinadas em algum lugar na universidade

\footnotetext{
2 "Filosofia analítica e Filosofia transformadora" e "O declínio da verdade redentora e a ascensão da cultura literária", In RORTY, R. \& GHIRALDELLI JR., P. Ensaios pragmatistas: sobre subjetividade e verdade. Rio de Janeiro: DP \& A, 2006.

3 A importância da idéia de utopia na obra madura de Rorty pode ser percebida em trechos como 0 seguinte, em que ele critica 0 antiutopianismo do pensamento francês contemporâneo, especialmente de Lyotard: "Nenhum evento - nem mesmo Auschwitz - pode mostrar que nós devemos cessar de trabalhar por uma dada utopia. Só outra utopia, mais persuasiva, pode fazer isso." (Objetivismo, relativismo e verdade, p. 292.). O teor de tal utopia, que recebe nomes diversos em outros textos de Rorty, tais como utopia vaga ou utopia liberal, será tratado ao longo do texto.

${ }^{4}$ Ensaios pragmatistas: sobre subjetividade e verdade, p. 49.
} 
(pelos cientistas políticos, ou pelos professores de literatura comparada, ou pelos historiadores das idéias, por exemplo). ${ }^{5}$

Obviamente, tal guinada ${ }^{6}$ foi objeto de espanto e de crítica. Tal reação não pode surpreender se lembrarmos que Rorty, ao menos até a publicação de sua mencionada obra-prima, era plenamente reconhecido como membro da tradição analítica, inserção que, segundo ele mesmo, pode ser quase "naturalizada" diante do contexto da época, pois até que “(...) tivesse terminado a graduação e o serviço militar, era 1958. Até então, estava claro que, se você não soubesse sobre filosofia analítica, não arrumaria um bom emprego"7. Assim, o que realmente surpreendeu é que, "passando para o outro lado", Rorty foi diversas vezes criticado por alguns dos pensadores "continentais" dos quais mais esteve próximo, especialmente Gianni Vattimo e Jürgen Habermas. Todavia, justamente tais críticas, que jamais impediram o constante diálogo com Rorty e mesmo uma admiração confessa de ambos por ele, constituem uma possibilidade interessante de acesso ao trajeto "continental” do pensador americano, isto é, de compreensão de significativa parte dos problemas e soluções que foram tratados por ele nos textos da maturidade "pós-analítica”. Nesse sentido, as críticas de Vattimo ${ }^{8}$, embora não tenham obtido resposta mais articulada de Rorty, diminuindo seu poder esclarecedor sobre este, podem ser úteis para desfazer o excesso de tensão entre as imagens simplistas de um Habermas obsoletamente fundacionista e de um Rorty sensatamente pós-metafísico, o que permite uma apreciação mais justa do constante e profícuo diálogo Habermas-Rorty que, para além dos elementos de tensão, possui um pano de fundo repleto de valores democrático-liberais compartilhados. Tal diálogo, constituído em boa parte pelas respostas do segundo às críticas do primeiro, foi importante para Rorty

5 Op. cit, p. 50.

${ }^{6}$ Que se tratou de uma guinada radical é o que fica demonstrado por textos como o seguinte, em que Rorty não apenas aponta para o fracasso do "projeto analítico", como se refere aos seus cultores com a inequívoca expressão de distanciamento "eles": "(...) os filósofos analíticos fracassaram completamente em fazer o que eles mais esperaram fazer: pôr a filosofia no caminho seguro de uma ciência." (Ensaios pragmatistas: sobre subjetividade e verdade, p. 50).

${ }^{7}$ Op. cit, p. 54.

8 Um exemplo significativo desta crítica de Vattimo e da sua tentativa, em direção oposta à de Rorty, de delimitar as fronteiras entre filosofia e literatura pode ser encontrado nos ensaios "A verdade da hermenêutica" e "Reconstrução da racionalidade", contidos como apêndice em: VATTIMO, G. Para além da interpretação - o significado da hermenêutica para a filosofia. Rio de Janeiro: Tempo Brasileiro, 1999. 
na construção de sua proposta utópica madura, de modo que o exame daquelas críticas permite uma melhor compreensão desta última.

O que pretendo mostrar a seguir é: (1) as críticas de Vattimo à assimilação da filosofia pela literatura, proposta por Rorty, na medida em que funcionam como uma espécie de mediação entre o (risco de) esteticismo deste último e o (risco de) retorno ao fundacionismo de Habermas; (2) o pano de fundo das críticas habermasianas a Rorty, a saber, sua tentativa de retomar o projeto da modernidade, não "funciona" para produzir uma espécie de "admoestação" capaz de "chamar à responsabilidade" política o pensador americano, isto é, de alinhá-lo com o próprio Habermas na polêmica contra o neo-conservadorismo pós-moderno9 ${ }^{9}$, já que Rorty não deseja adotar, além dos compartilhados valores democrático-liberais, também o vocabulário neoiluminista do pensador alemão, mas deseja criar um novo vocabulário; (3) o esteticismo, baseado neste desejo de criação, de que Habermas acusa Rorty não é um erro teórico cometido involuntariamente por este, mas coincide com sua estratégia em busca da utopia liberal, parcialmente construída a partir da necessidade de defesa diante da crítica habermasiana, estratégia baseada em uma radical separação entre as esferas pública e privada ${ }^{10}$, sendo esta última inevitavelmente dominada pelo pathos esteticista da criação lingüística.

\section{(1)}

As críticas de Vattimo são sempre em relação ao risco de esteticismo a que se expõe Rorty, em virtude de seu posicionamento buscando a inclusão da filosofia na literatura ${ }^{11}$, na medida em que tal inclusão parece vir acompanhada por uma renúncia ao jogo argumentativo como instância

\footnotetext{
9 "Vamos pois rapidamente distinguir 0 anti-modernismo dos jovens conservadores do pré-modernismo dos antigos conservadores e do pós-modernismo dos neo-conservadores" (HABERMAS, J. "Modernidade versus Pós-modernidade", In Arte em revista, n 7, p. 86/91, 1983).

10 "(...) abandonamos a exigência de uma teoria que unifique o público e o privado, e nos contentamos em tratar as demandas de autocriação e de solidariedade humana como igualmente válidas, mas definitivamente incomensuráveis" (RORTY, R. Contingência, ironia e solidariedade. São Paulo: Martins Fontes, 2007, p. 18).

11 "De dentro de uma cultura literária, a religião e a filosofia aparecem como gêneros literários" (Ensaios pragmatistas: sobre subjetividade e verdade, p. 78).
} 
última: "Em conformidade com meus próprios preceitos, não oferecerei argumentos contra o vocabulário que quero substituir. Tentarei, ao contrário, fazer com que o vocabulário que prefiro pareça atraente (...)"12. Assim, embora Vattimo e Rorty viessem apresentando posições ético-políticas cada vez mais próximas até a morte deste último, chegando mesmo, três anos antes desta, a publicar juntos um livro repleto de manifestações de convergência, as críticas de Vattimo permaneceram e não foram claramente rejeitadas por Rorty, talvez porque este tenha julgado que o fundo comum a ambos permitia uma mescla capaz de tornar pouco significativa a censura vattimiana pelo seu suposto esteticismo: "Os argumentos de Vattimo fornecem uma ilustração de como linhas de pensamento saídas de Nietzsche e Heidegger podem ser mescladas com aquelas vindas de James e Dewey"13. Ora, o fato é que, embora ambos reconhecessem a fecundidade desta mescla entre neopragmatismo e hermenêutica, Vattimo permaneceu distante de Rorty quanto ao significado a ser atribuído ao jogo argumentativo, considerando que a filosofia não deveria ser reduzida a um gênero literário, descompromissado com a argumentação, sob pena de absoluta incompreensão dos textos filosóficos, “(...) se começamos não levando a sério o propósito principal que tinham em vista os autores, isto é, o propósito de escrever filosofia (verdades argumentadas, 'científicas', ao menos em sua perspectiva) e não pura poesia ou narrativa(..)"14 (tradução nossa). Assim, para Vattimo, em que pesem a força e a amplitude da mescla proposta por Rorty, que podem ser expressas pela concordância de ambos quanto a uma concepção de filosofia não mais compreendida como discurso fundador e capaz de atingir uma suposta essência ou estrutura última da realidade ${ }^{15}$, mas como uma "ontologia da atualidade" ou "hermenêutica filosófica", apta apenas a interpretar nosso mundo histórico, pós-metafísico, isto não significa

12 Contingência, ironia e solidariedade, p. 35.

${ }_{13}$ RORTY, R. e VATTIMO, G. O futuro da religião: solidariedade, caridade e ironia. Organização Santiago Zabala. Rio de Janeiro: Relume-Dumará, 2006, p. 55.

14 VATTIMO, G. Nichilismo ed emancipazione - Etica, politica, diritto. Milão: Garzanti Libri, 2003, p. 36.

15 "Os meus ensaios deverão ser lidos como exemplos do que um grupo de filósofos italianos chamou 'pensamento débil' - reflexão filosófica que não tenta fazer uma crítica radical da cultura contemporânea, não tenta refundá-la ou remotivá-la, mas simplesmente reúne chamadas de atenção e sugere algumas possibilidades interessantes." (RORTY, R. Ensaios sobre Heidegger e outros. Lisboa: Instituto Piaget, p. 22). O "pensamento débil" a que se referiu Rorty é o nome de uma coletânea de 1983, II pensiero debole, organizada por Gianni Vattimo e Píer Aldo Rovatti, cujo título se tornou uma espécie de marca registrada do pensamento de Vattimo. 
que ela, a filosofia, possa renunciar ao caráter argumentativo, sob pena de ficar incapacitada sob o signo de uma mera arbitrariedade esteticista:

Pretendo sustentar aqui (...) uma noção específica de racionalidade que, sem retornar aos procedimentos fundadores da tradição metafísica, não cancele completamente as características específicas do discurso filosófico, enquanto distinto, por exemplo, da poesia e da literatura. ${ }^{16}$

Esta proposta de "uma noção específica de racionalidade" pode ajudar, como já dissemos, a desfazer certa tensão entre Habermas e Rorty, evitando uma oposição forte demais entre racionalidade fundacionista e redescrição criadora, com a posição de Vattimo funcionando como uma mediação entre ambas, ao deixar ver como alguém (Rorty) que, "em conformidade com seus próprios preceitos”, se recusa a oferecer argumentos pode sofrer a influência de outro (Habermas) que deseja fornecê-los e, ao mesmo tempo, exigi-los:

Habermas considera essencial para as sociedades democráticas que sua auto-imagem encarne o universalismo e alguma forma do racionalismo iluministas. (...) Não quero atualizar o universalismo nem o racionalismo, e sim dissolver os dois e substituí-los por outra coisa. ${ }^{17}$

A mediação de Vattimo incide justamente entre a expectativa habermasiana por "alguma forma do racionalismo" e o desejo de Rorty de "dissolver os dois", racionalismo e universalismo, e "substituí-los por outra coisa”. As críticas de Vattimo indicam que mesmo se partilhando com Rorty uma concepção não fundacionista, antiessencialista, historicista e nominalista da filosofia, é possível ser contra a sua absorção esteticista pela literatura, através de uma "decisão interpretativa" de permanecer no âmbito argumentativo: "Uma filosofia da universalidade secularizada e enfraquecida argumenta, discute, 'perturba', justamente baseando-se no critério do enfraquecimento e da secularização"18 (tradução nossa). Ora, em que pesem

\footnotetext{
16 Para além da interpretação - o significado da hermenêutica para a filosofia, p. 139.

17 Contingência, ironia e solidariedade, p. 126.

18 Nichilismo ed emancipazione - Etica, politica, diritto, p. 45.
} 
algumas advertências explícitas propondo o contrário, é possível encontrar nos textos de Rorty, junto às suas tentativas de redescrição criadora e de dissolução de problemas a partir de juízos de gosto, diversas outras passagens baseadas no mesmo tipo de argumentação "enfraquecida” descrito por Vattimo, que o pensador americano prefere denominar, por oposição a argumentos lógicos, como argumentos dialéticos: "A forma preferida de argumentação do ironista é a dialética (...). Assim, ele pensa na lógica como um auxiliar da dialética (...)"19. Portanto, o que parece resultar da abordagem da crítica de Vattimo a Rorty é que este, ao contrário do que poderia parecer a partir de seus embates diretos com Habermas, marcados pela censura em relação à retórica iluminista habermasiana, também recorre à argumentação, ainda que dialética, enfraquecida ou hermenêutica. Isto permite compreender o que torna Rorty sensível à argumentação, especialmente à habermasiana, a ponto de pretender defender o ironismo contra as investidas do pensador alemão: “(...) quero defender o ironismo, bem como o hábito de tomar a crítica literária como a disciplina intelectual preponderante, de polêmicas como a de Habermas." 20

\section{(2)}

Como as de Vattimo, as críticas de Habermas são habitualmente contrabalançadas pelo seu reconhecimento de fundamentais pontos em comum com Rorty, mas não têm uma direção constante, variando entre a censura pela adesão a um esteticismo de perfil nietzschiano ${ }^{21}$ e pela suposta despedida da filosofia: “(...) sou freqüentemente caracterizado como um filósofo do 'fim-da-filosofia'. Mas não sou”22. Pela amostra, percebe-se que Rorty não deixou, como fez com relação a Vattimo, as críticas habermasianas sem resposta, embora seu tom tenha sido, em geral, algo irônico e amistoso, vendo nelas uma forma de exortação e percebendo sua progressiva

\footnotetext{
${ }^{19}$ Contingência, ironia e solidariedade, p. 141.

20 Op. cit., p. 149.

21 "Vê-se como o pathos nietzschiano de uma filosofia da vida aplicada à lingüística anuvia os sóbrios discernimentos do pragmatismo (...)" (HABERMAS, J. O discurso filosófico da modernidade. São Paulo: Martins Fontes, 2002, p. 289).

22 Ensaios pragmatistas: sobre subjetividade e verdade, p. 68.
} 
diminuição ao longo dos anos como mostra de uma crescente convergência entre "companheiros" na luta pelos valores das democracias liberais. ${ }^{23}$

Todavia, se quisermos mostrar a divergência entre estes companheiros de forma esquemática, podemos recorrer às respectivas auto-imagens. Habermas se vê como alguém que crê na possibilidade de uma "fundamentação", ainda que fraca, no âmbito de uma renovada e incompleta modernidade, pois pensa que "(...) as formas moderadas de fundamentação transcendental e dialética podem perfeitamente ser úteis (...)"24. Rorty, por sua vez, se considera “(...) um convicto holista, historicista, pragmatista e contextualista (...)", em suma, um pragmatista ironista e liberal ${ }^{25}$, como ele mesmo se compreende em textos diversos, e que, como tal, não crê na fecundidade nem na possibilidade de qualquer fundamentação, preferindo um vocabulário “(...) que gira em torno de idéias de metáfora e autocriação (...), [pois] seu método é mais a redescrição do que a inferência"26. Assim, mesmo reconhecendo uma comunhão de finalidades, Rorty se esforçou por mostrar que a estratégia de Habermas, ao permanecer no interior do pensamento metafísico ou, o que dá no mesmo nesse caso, ao se fixar em uma metanarrativa de caráter fundacionista, que pensa como inacabado o projeto de emancipação da modernidade, é claramente inapta para alcançar aquilo a que se propõe, já que “(...) o vocabulário do racionalismo iluminista, apesar de ter sido essencial nos primórdios da democracia liberal, tornou-se um empecilho à preservação e ao progresso das sociedades democráticas." 27

Este polêmico "empecilho" entrou na ordem do dia desde que o tema da pós-modernidade passou a ser tratado filosoficamente, isto é, desde que Jean-François Lyotard escreveu seu livro “A condição pós-moderna” em 1979, classificando o "vocabulário do racionalismo iluminista" como uma das metanarrativas em que se deixou de acreditar. A partir daí, defendendo a idéia de que tal vocabulário ainda pudesse servir à causa das sociedades

\footnotetext{
23 "Autores como Marx, Mill, Dewey, Habermas e Rawls são mais como companheiros cidadãos. Engajam-se em um esforço social compartilhado" (Contingência, ironia e solidariedade, p. 17).

${ }^{24}$ HABERMAS, J. Consciência moral e agir comunicativo. Rio de Janeiro: Tempo brasileiro, 2003, p. 30.

25 Rorty desenvolve longamente a idéia de "ironismo", cujo núcleo pode ser encontrado em um radical contingencialismo, na obra Contingência, ironia e solidariedade, p. 133 e seguintes. Os ironistas são pessoas "nunca propriamente capazes de se levarem a sério, por estarem sempre cônscias de que os termos em que se descrevem são passíveis de mudança e sempre cônscias da contingência e fragilidade de seus vocabulários finais".

${ }^{26}$ Contingência, ironia e solidariedade, p. 141.

${ }^{27}$ Op. cit., p. 90.
} 
democráticas, Habermas entrou em acirrada e permanente polêmica com todos que considerou defensores da existência de uma pós-modernidade ou que manifestassem posições convergentes com aqueles filósofos que passaram a ser denominados como pós-modernos, entre eles, o próprio Rorty: "Aqueles que, como eu, são acusados de frivolidade pós-moderna (...)"28. Esta polêmica de Habermas foi apresentada pela primeira vez em um discurso, logo no ano seguinte ao mencionado livro de Lyotard, no recebimento do Prêmio Adorno, programaticamente intitulado de "Modernidade - um projeto inacabado": "Acho que em vez de renunciar à modernidade e a seu projeto como uma causa perdida, deveríamos aprender a lição dos enganos daqueles programas extravagantes que tentaram negá-la"29. Para Habermas, estes "programas extravagantes" que tentaram negar a modernidade, articulados em torno do Surrealismo e desembocando no pós-modernismo, fracassaram estrondosamente em superar um dos momentos estruturais daquela, que é o processo de autonomização da esfera da arte em relação à cultura como um todo: “(...) todas as tentativas de conduzir arte e vida, ficção e práxis, aparência e realidade ao mesmo plano; (...) as tentativas de proclamar tudo arte e todos artistas, (...) todos esses projetos mostraram-se algo absurdos"30. Esta tentativa fracassada no âmbito da arte sofreu o mesmo destino no âmbito teórico: "Há no âmbito do conhecimento teórico, (...) exemplos paralelos desta malograda tentativa do que poderíamos chamar falsa negação da cultura. (...) Desde os tempos dos jovens hegelianos tem-se falado da negação da filosofia" 31 . Essas correntes de pensamento que buscaram negar a autonomia da arte, dissolvendo-a novamente no todo da cultura, e também a continuidade da tradição filosófica, reduzindo-a à experiência estéticoliterária, são consideradas por Habermas como pós-modernas exatamente na medida em que tentaram negar a divisão da cultura em esferas autônomas, entrevista no criticismo kantiano e tematizada por Weber, que constituiria o que há de mais profícuo na modernidade:

A dignidade própria da modernidade cultural consiste naquilo que Max Weber denominou a diferenciação específica

\footnotetext{
${ }^{28}$ Ensaios pragmatistas: sobre subjetividade e verdade, p. 76.

${ }_{29}$ Modernidade versus Pós-modernidade, p. 89.

${ }^{30}$ Op. cit., p 89.

${ }^{31}$ Op. cit., p. 89.
} 
das esferas de valor. (...) Questões de verdade, justiça e gosto podem então ser elaboradas e desdobradas segundo suas respectivas lógicas internas. ${ }^{32}$

Como se pode perceber, as críticas que Habermas dirige a Rorty, bem como àquela parte da filosofia contemporânea que ele considera pósmoderna, têm como pano de fundo constante uma metanarrativa neoiluminista que pretende mostrar que a modernidade é, justamente, um "projeto inacabado", já que ainda não teriam sido levadas a cabo as conseqüências mais fecundas desta diferenciação entre ciência, moral e arte, fecundidade que ele vê na possibilidade de que tais esferas autônomas, após desencantar, como dizia Weber, o mundo da vida, depauperando-o pela dissolução dos sistemas metafísico-religiosos tradicionais, poderiam agora fecundá-lo de forma ainda mais rica: “(...) o projeto da modernidade ainda não se cumpriu (...). Ele visa a modificar os laços da cultura moderna com a práxis da cultura cotidiana que ainda depende de heranças vitais, mas que se veria empobrecer se limitada ao mero tradicionalismo" ${ }^{33}$. A crença nesta renovada "metanarrativa de emancipação" é que realmente provoca as críticas habermasianas a Rorty. De fato, o que está verdadeiramente em questão nelas, e que é argutamente percebido pelo pensador americano, é a pressuposição de que "abandonar um ponto de vista que é, senão transcendental, pelo menos 'universalista', parece a Habermas trair as esperanças sociais que foram centrais para a política liberal" 34 . Para o pensador alemão, esta traição é cometida por toda a tradição de pensamento que, a partir de Nietzsche, pretendendo ter deixado para trás o projeto da Aufklãrung, iniciou uma crítica radical e totalizante da racionalidade, impossibilitando uma fundamentação racional na busca por verdades universais essenciais à utopia do Esclarecimento: "Ao voltar-se contra a razão, enquanto fundamento de sua própria validade, a crítica torna-se total." 35

Segundo Habermas, esta "crítica da crítica" possui uma origem inequívoca no esteticismo nietzschiano, que contamina a tradição filosófica continental até desembocar na chamada pós-modernidade: "A comparação

\footnotetext{
32 O discurso filosófico da modernidade, p. 161.

33 Modernidade versus Pós-modernidade, p. 90.

${ }^{34}$ Ensaios sobre Heidegger e outros, p. 258.

${ }^{35} \mathrm{O}$ discurso filosófico da modernidade, p. 169.
} 
com Nietzsche é instrutiva na medida em que chama a atenção para o horizonte de experiência estética que motiva e dirige o olhar que realiza o diagnóstico"36. É exatamente na adoção deste horizonte que Habermas vê o risco de queda no esteticismo nietzschiano que critica em Rorty: "a forma discretamente subversiva do ócio associa-se então a uma fantasia elitista da criação lingüística" ${ }^{37}$. Para ele, ao compartilhar tal horizonte estético, Rorty não teria mais como fundamentar sua preferência pelos valores das democracias liberais, mas ficaria restrito a anunciá-la como mero juízo de gosto. Assim, na perspectiva habermasiana, embora a autonomia da esfera estética, enquanto conquista da modernidade, esteja apta a tratar suas próprias questões de gosto segundo uma perspectiva interna, por isto mesmo ela não pode cuidar das questões relativas à verdade e à justiça, sob pena daquilo que ele denomina como esteticismo, isto é, uma invasão colonizadora por parte da esfera estética em relação às outras esferas da cultura, pois "são as questões de gosto que respondem à pergunta pelo 'valor' da verdade e da justiça." 38

Todavia, diante desta polêmica habermasiana contra os adversários do Esclarecimento, agrupados sob o rótulo da pós-modernidade, Rorty ocupa uma posição atípica e, de certa forma, intermediária, que ele costumava abreviar com a expressão autodescritiva "ironista liberal". Uma amostra desta posição intermediária pode ser colhida na preocupação de Rorty de defender sua posição diante de Habermas, como fica claro em uma longa passagem que ilustra o caráter paradigmático da relação "ataque-defesa" entre ambos:

É que a metafísica está entremeada na retórica pública das sociedades liberais modernas. O mesmo ocorre com a distinção entre o moral e o "meramente" estético (...). Esta situação levou a acusações de "irresponsabilidade" contra os intelectuais ironistas. Algumas delas vieram de ignorantes (...). As mesmas acusações, porém, são feitas por autores que sabem do que estão falando (...). (...) o mais importante desses autores é Habermas, que montou uma polêmica contínua, pormenorizada e cuidadosamente ponderada contra os

${ }^{36}$ Op. cit., p. 183.

${ }^{37}$ Consciência moral e agir comunicativo, p. 29.

38 O discurso filosófico da modernidade, p. 176. 
críticos do Iluminismo (...). (...) quero defender o ironismo, bem como o hábito de tomar a crítica literária como a disciplina intelectual preponderante, de polêmicas como a de Habermas. ${ }^{39}$

Esta preocupação demonstrada por Rorty não se deve apenas ao reconhecimento da consistência da polêmica de Habermas, mas ao fato de compartilhar com este tanto o valor das instituições democráticas tradicionais como o tipo de aperfeiçoamento que lhes é adequado, ainda que discordem radicalmente quanto ao uso do tradicional jargão universalista associado à defesa da democracia, jargão ou vocabulário considerado obsoleto pelo primeiro e essencial pelo segundo:

Eu uso a expressão "pós-modernismo" no sentido dado a esse termo por Jean François Lyotard, que diz que a atitude pósmoderna é a atitude de "desconfiar de metanarrativas"(...). [E se] é difícil desenredar instituições liberais burguesas do vocabulário que essas instituições herdaram do Iluminismo (...), eu quero mostrar como esse vocabulário (...) pode ser reinterpretado para se adaptar às nossas necessidades, às necessidades dos liberais burgueses pós-modernos. ${ }^{40}$

Se, por um lado, este vocabulário da emancipação, herdado pelo ironista liberal Rorty e que também constitui a proveniência histórica de Habermas, deve ser reinterpretado para se adaptar "às necessidades dos liberais burgueses pós-modernos”, é inevitável, por outro, que tal reinterpretação seja atingida pela crítica habermasiana ao esteticismo e

${ }^{39}$ Contingência, ironia e solidariedade, p. 149.

40 Objetivismo, relativismo e verdade, p. 266. Mais tarde, Rorty passou a ver como desvantajoso o uso do termo "pós-moderno", devido à sua excessiva utilização e à sua indevida generalização: "Utilizei por vezes o termo 'pós-moderno' no seu sentido mais estrito definido por Lyotard como 'desconfiança das metanarrativas'. Mas agora preferiria não o ter feito. 0 termo tem sido tão utilizado que causa mais problemas que o necessário" (Ensaios sobre Heidegger e outros, p. 16). Todavia, isto não significa que ele deixou de concordar com Lyotard quanto a ver a perda de credibilidade nas metanarrativas como uma significativa característica da época atual, bem como a vê-las como algo a ser sensatamente evitado, como se pode perceber em um dos ensaios deste mesmo livro: "Poderíamos concordar com Lyotard que estudos da competência comunicativa de um sujeito trans-histórico [do tipo elaborado por Habermas] são de pouca utilidade no reforçar do nosso sentido de identificação com a nossa comunidade (...). Narrativas históricas detalhadas (...) tomariam o lugar de metanarrativas filosóficas." (Idem, p. 273). 
conservadorismo pós-modernos. Resta mostrar por que ironistas liberais como Rorty, ao contrário do que ocorre com alguém como Lyotard, não podem simplesmente deixar para trás o vocabulário da emancipação e, em conseqüência, ficam ainda mais expostos, devido ao efeito do contraste, à acusação de esteticismo oriunda de defensores de tal vocabulário, como Habermas.

O cunho propositivo da utopia rortiana, sua busca de reinterpretar (e não de desconstruir ou de ignorar, por exemplo) o vocabulário Iluminista de acordo com "as necessidades dos liberais burgueses pós-modernos" como o próprio Rorty, o deixa em uma posição rara diante da querela entre modernidade e pós-modernidade, personificada por aquela entre Habermas e Lyotard, já que: "Como Lyotard, nós queremos abdicar de metanarrativas [como a de Habermas]. Ao contrário dele, nós continuamos a tecer narrativas edificantes de primeira ordem"41. Essa oposição entre aquilo que é herdado da tradição e as criações capazes de renová-lo foi uma constante na obra madura de Rorty:

Essa forma de delinear o contraste permite-nos pensar num momento "literário" ou "poético" ocorrendo periodicamente em muitas áreas da cultura - ciência, filosofia, pintura e política (...). É o momento em que as coisas não estão a correr bem (...), [momento] tão sobrecarregado com o que Thomas Kuhn chama "anomalias" que é necessário um novo começo. ${ }^{42}$

Tal oposição foi pensada por ele, em momentos diversos, como ocorrendo entre epistemologia e hermenêutica, entre metáforas vivas e mortas, entre vocabulários velhos e novos ou entre metanarrativas e narrativas edificantes. Assim, a construção do vocabulário da sua utopia liberal a partir da oposição ao vocabulário iluminista de Habermas, a construção das narrativas edificantes por oposição às metanarrativas, não fez senão confirmar essa estratégia rortiana, agudamente diagnosticada por Vattimo: "A quase simétrica inversão da ética da comunicação [partilhada por Apel e Habermas] pode ser vista na teoria das redescrições de Richard

41 Objetivismo, relativismo e verdade, p. 282.

${ }^{42}$ Ensaios sobre Heidegger e outros, p. 146. 
Rorty. E não é inverossímil que se tenha construído exatamente em relação polêmica contra ela"43. A tessitura de tais narrativas edificantes, que busca edificar a utopia adequada às necessidades dos ironistas liberais e que, portanto, depende de um novo vocabulário, vai sendo produzida como resposta a críticas como as de Habermas, já que os ironistas precisam de algo a que ironizar: “(...) o ironista não pode arranjar-se sem o contraste entre o vocabulário final que herdou e aquele que tenta criar para si mesmo" 44 . Portanto, o ironista permanece necessariamente entre dois vocabulários finais, ficando exposto ao efeito do contraste entre aquele que considera obsoleto e aquele que ainda não pode reivindicar mais do que o próprio gosto como sua sustentação:

Físicos revolucionários, políticos e filósofos sempre pegaram nas palavras e as moldaram em novas formas. Deram desse modo razão aos seus zangados oponentes conservadores, acusando-os de apresentar novos e estranhos sentidos para expressões conhecidas, de fazer trocadilhos frivolamente, de já não seguirem as regras, de usarem a retórica em vez da lógica, imagens em vez de argumentos. ${ }^{45}$

\section{(3)}

Segundo o vocabulário empregado pelo próprio Rorty, vivemos na época pós-moderna ou pós-metafísica, isto é, de perda de credibilidade das metanarrativas teleológicas e de impossibilidade de sustentar qualquer fundacionismo: “(...) a maioria dos intelectuais contemporâneos vive numa cultura que está autoconscientemente sem archai, sem telos, sem teologia, teleologia ou ontologia"46. Esta autoconsciência é o que faz com que sejam raras no cenário filosófico tanto as utopias, no estilo daquela do Esclarecimento parcialmente renovada por Habermas, como as distopias, do tipo de "1984", de George Orwell, ou de "Admirável mundo novo", de

\footnotetext{
${ }^{43}$ Para além da interpretação - o significado da hermenêutica para a filosofia, p. 56.

${ }^{44}$ Contingência, ironia e solidariedade, p. 156.

${ }^{45}$ Ensaios sobre Heidegger e outros, p. 160.

${ }^{46}$ Op. cit., p. 63.
} 
Aldous Huxley, tão influentes no pessimismo filosófico do século passado (basta pensar em Adorno e Foucault para percebê-lo). De fato, "sem archai e sem telos", isto é, sem possibilidade de fundar mudanças radicais na cultura, para levá-la a fins universalmente desejáveis, nem de prognosticar um futuro sombrio desviado de tais fins, o desejo de Rorty de continuar "tecendo narrativas edificantes” parece deixá-lo em uma posição atípica diante da "maioria dos intelectuais contemporâneos", uma posição entre extremos como Habermas e Lyotard. De fato, Rorty compartilha com o último a percepção da perda de credibilidade das metanarrativas, mas pensa, ao contrário dele, que "Nenhum evento - nem mesmo Auschwitz - pode mostrar que nós devemos cessar de trabalhar por uma dada utopia" 47 . Quanto a Habermas, se fica clara uma convergência entre suas posições políticas e as de Rorty, em torno dos valores das sociedades democráticas, também se impõem divergências filosóficas, especialmente sobre as relações, fundacionistas ou não, entre posições filosóficas e políticas, assumidamente utópicas ou não: “(...) minhas discordâncias com relação a Habermas são o que se costuma chamar de diferenças 'meramente filosóficas.." 48

Como já visto, estas diferenças motivam a acusação de esteticismo contra Rorty, para quem “(...) uma utopia liberal seria uma cultura poetizada (...), [pois] Habermas encara [este] discurso estetizante sobre a metáfora, a novidade conceitual e a invenção de si mesmo como uma preocupação lamentável (...)"49. Ele considera lamentável o "discurso estetizante” de Rorty justamente pela sua incapacidade de sustentar, de alguma forma, as práticas e instituições políticas que ambos consideram como suas. Tal acusação de esteticismo é inevitável, considerando-se o posicionamento voltado para "a invenção de si mesmo" do pensador americano, isto é, devido ao seu ironismo, que deriva: 1) de uma posição de dúvida permanente quanto ao seu próprio vocabulário, devido ao contato com inúmeros vocabulários alternativos, por exemplo, os de Habermas e Lyotard; 2) da percepção de que nenhuma argumentação é capaz de desfazer tais dúvidas e 3) da descrença quanto à possibilidade de que qualquer vocabulário, inclusive o próprio, esteja em condições de se aproximar da realidade assim como é, obtendo o

47 Objetivismo, relativismo e verdade, p. 292.

${ }^{48}$ Contingência, ironia e solidariedade, p. 125.

${ }^{49}$ Op. cit., p. 123. 
conhecimento de um fundamento capaz de orientar definitiva e universalmente todos os vocabulários alternativos possíveis. ${ }^{50}$

A partir deste posicionamento ironista, fica claro o porquê Rorty não pode compartilhar o vocabulário neoiluminista de Habermas, já que este pressupõe tudo aquilo que o ironista rejeita, a saber, a crença na possibilidade de adquirir argumentativamente um vocabulário final universal capaz de atingir o "fundo da realidade", a verdade redentora, aquilo que deveria encerrar a busca sobre o fim supremo da humanidade, pois: "A premissa da filosofia [inclusive de Habermas] é a de que existe um modo como as coisas realmente são (...). O conhecimento desse modo é redentor" ${ }^{51}$. Assim, a oposição entre as dúvidas ironistas e a crença na verdade redentora opõe, por um lado, o posicionamento historicista, nominalista e contextualista de Rorty, típico dos "liberais burgueses pós-modernos", e por outro o transcendentalismo fundacionista, ainda que mitigado, do vocabulário neoiluminista de Habermas, para quem “(...) as formas moderadas de fundamentação transcendental e dialética podem perfeitamente ser úteis(...)"52. Neste ponto, todavia, já deve estar claro que o vocabulário do ironista, "sem archai e sem telos", não possui nem pretende possuir nenhuma utilidade, exceto a de lhe permitir a "invenção de si mesmo" e de modo algum a de propiciar o fortalecimento e a continuidade das sociedades democrático-liberais. Mas também já deve estar claro que nenhum vocabulário pode fazê-lo atualmente, nem mesmo o neoiluminista de Habermas, pois a falta de archai e de telos também o atinge, mesmo contra vontade, sob a figura da inexorável perda de credibilidade das metanarrativas.

Diante de tudo isso, impõe-se a questão da (in)compatibilidade entre ironismo e utopia. Como é possível que Rorty defenda que não "devemos cessar de trabalhar por uma dada utopia”? Como é possível que ele defenda valores democrático-liberais de conteúdo fortemente utópico, por exemplo, a solidariedade ou o cosmopolitismo, elogiados em diversos textos, com um vocabulário "que gira em torno de idéias de metáfora e autocriação" e que é voltado para "a invenção de si mesmo"? Alguém poderia extrair uma explicação, utilizável como uma acusação de utilitarismo ć́nico contra o

\footnotetext{
50 Cf. Contingência, ironia e solidariedade, p. 133 e seguintes.

${ }^{51}$ Ensaios pragmatistas: sobre subjetividade e verdade, p. 82.

52 Consciência moral e agir comunicativo, p. 30.
} 
ironismo, a partir da constatação do próprio Rorty, segundo o qual: "O ironista é o típico intelectual moderno e as únicas sociedades que lhe dão a liberdade de articular sua alienação são as liberais" ${ }^{\text {" } 3}$. Mas essa acusação só teria força do ponto de vista de um vocabulário como o de Habermas, que julgasse haver razões transcendentes capazes de justificar, diante de todos e definitivamente, uma superioridade das sociedades liberais, pois do ponto de vista de um vocabulário ironista, "a idéia de que as sociedades liberais são unidas por crenças filosóficas me parece ridícula. $\mathrm{O}$ que une as sociedades são os vocabulários comuns e as esperanças comuns" ${ }^{2}$. Aquilo que não parece ridículo, mas sensato, do ponto de vista de Rorty, é atribuir tal comunidade de vocabulários e esperanças ao pertencimento àquilo que Habermas denomina "forma de vida sócio-cultural" e que Vattimo costuma nomear como "proveniência histórica", em suma, o pertencimento a uma comunidade que compartilha certo vocabulário final herdado e contingente. No caso das sociedades liberais contemporâneas, esta comunidade de vocabulários e esperanças reúne-se em torno da crença, indemonstrável e consensual, de que “(...) o objetivo da organização social é permitir que todos tenham a oportunidade de criar a si mesmos, segundo o melhor de sua capacidade, e de que essa meta requer, além de paz e riqueza, as 'liberdades burguesas' de praxe." 55

È por isso que, no fim das contas, não é possível deixar de perceber que a perspectiva de Rorty é significativamente mais fecunda do que a apresentada pelo pensador alemão, já que aquela parece conseguir "levar adiante", no sentido de apresentá-la persuasivamente como melhor do que as alternativas, a herança comum que ambos gostariam de fortalecer, as instituições e práticas liberais democráticas, de um modo essencialmente nãonostálgico, não fundacionista e independente de metanarrativas teleológicas universais que não se sustentam mais: “(...) tentarei reformular as esperanças da sociedade liberal de um modo não racionalista e não universalista - um modo que favorece mais a concretização delas do que faziam as descrições mais antigas" 56 . Este modo de "reformular as esperanças" mostra-se, mais do que posições concorrentes como as de Habermas e Lyotard, como capaz de

\footnotetext{
${ }^{53}$ Contingência, ironia e solidariedade, p. 158.

54 Op. cit., p. 154.

55 Op. cit., p. 151.

${ }^{56}$ Op. cit, p. 90.
} 
reunir, em torno de sua utopia liberal: 1) metafísicos liberais, como Habermas, ansiosos por "fundar" a liberal-democracia; 2) "adversários" niilistas pós-modernos, como Lyotard, também interessado em "articular sua alienação", mas "inclinados a tomar eventos históricos particulares como demonstrando a 'bancarrota' dos esforços de longo prazo para uma reforma social"57; e 3) ironistas liberais, como Rorty, para quem "a meta de uma sociedade justa e livre é deixar que seus cidadãos sejam tão privatistas, 'irracionalistas' e esteticistas quanto lhes aprouver." 58

De fato, a utopia liberal imaginada por Rorty não deve ser compreendida como o estabelecimento de um predomínio da "cultura literária”, como uma extensão colonizadora da esfera estética, temida por Habermas por julgar que questões de gosto responderiam à pergunta pelo "valor" da verdade e da justiça, pois embora Rorty se proponha a defender, justamente de polêmicas como a de Habermas, o hábito de tomar a crítica literária como a disciplina intelectual preponderante, isto não significa que ele proponha que todos devam tomá-la daquele modo. Longe disso, na utopia liberal, o espaço público não seria invadido pela esfera estética nem seria preciso "fundar" seus valores, pois, além da total impossibilidade de crença em um fundamento, a ser descrito por uma metanarrativa correspondente, tais valores seriam considerados desejáveis e compartilhados apenas como a apropriação de uma herança histórica contingente, expressa pelo vocabulário e pela esperança partilhados, como já visto ${ }^{59}$. O espaço público utópico seria o local de convívio de uma comunidade maximamente tolerante, para a qual questões religiosas, filosóficas ou literárias não seriam vistas como nada mais do que modos de inventar a si mesmos utilizados por tipos peculiares de cidadãos, questões totalmente inúteis para discussões pragmáticas voltadas para a contínua reconstrução da ordem política da utopia liberal, articulada a partir da tolerância com as idiossincrasias e da separação entre auto-criação privada e atuação pública: "Nessa utopia, a cultura literária não será a única, ou mesmo dominante, forma de cultura

\footnotetext{
57 Objetivismo, relativismo e verdade, p. 292.

${ }^{58}$ Contingência, ironia e solidariedade, p. 17.

59 "Habermas e outros metafísicos que desconfiam de uma concepção meramente 'literária' da filosofia acham que as liberdades políticas liberais requerem um certo consenso sobre o que é universalmente humano. Nós, ironistas que também somos liberais, cremos que tais liberdades não precisam de consenso quanto a nenhum tópico mais básico do que sua própria desejabilidade" (Contingência, ironia e solidariedade, p. 150).
} 
superior (...). Na utopia, a necessidade religiosa ou filosófica de viver à altura do não-humano e a necessidade dos intelectuais literários (...) serão vistas como questões de gosto" ${ }^{60}$. Assim, o entrelaçamento entre esteticismo e utopia, na perspectiva de Rorty, não é algo a ser lamentado como inevitável nem tampouco fundamentado argumentativamente, mas deve ser visto como um caminho possível para "um liberalismo iluminista maduro (descientifizado e desfilosofizado)." 61

${ }^{60}$ Ensaios pragmatistas: sobre subjetividade e verdade, p. 101.

${ }^{61}$ Contingência, ironia e solidariedade, p. 111. 


\section{Referências}

HABERMAS, J. "Modernidade versus Pós-modernidade". In Arte em revista, nª 7, p. 86/91, 1983.

. O discurso filosófico da modernidade. São Paulo: Martins Fontes, 2002.

. Consciência moral e agir comunicativo. Rio de Janeiro: Tempo brasileiro, 2003.

RORTY, R. Objetivismo, relativismo e verdade. Rio de Janeiro: Relume-Dumará, 2002.

. Contingência, ironia e solidariedade. São Paulo: Martins Fontes, 2007.

. Ensaios sobre Heidegger e outros. Lisboa: Instituto Piaget.

RORTY, R. \& GHIRALDELLI JR., P. Ensaios pragmatistas: sobre subjetividade e verdade. Rio de Janeiro: DP \& A, 2006.

RORTY, R. \& VATTIMO, G. O futuro da religião: solidariedade, caridade e ironia. Organização Santiago Zabala. Rio de Janeiro: Relume-Dumará, 2006.

VATTIMO, G. Para além da interpretação - o significado da hermenêutica para a filosofia. Rio de Janeiro: Tempo Brasileiro, 1999. Nichilismo ed emancipazione - Etica, politica, diritto. Milão: Garzanti Libri, 2003.

Email: rcaerca@uol.com.br

Recebido: 11/2009

Aprovado: 03/2010 